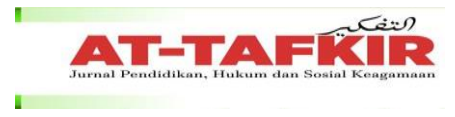

\author{
VOLUME 14 NOMOR I TAHUN 2021 \\ P-ISSN : 1979-9357 \\ E-ISSN : 2620-5858
}

\title{
Pendekatan Andragogi dalam Pengajian Sosialita Kota Langsa
}

\author{
Mukhlis \\ Institut Agama Islam Negeri (IAIN) Zawiyah Cot Kala Langsa \\ mukhlisrais80@gmail.com
}

\begin{abstract}
This article discusses the andragogy approach process carried out by the presenter Ustadz when filling out the recitation of socialite mothers who are active in the Taklim Amanah Council and the Taklim Hidayatullah Council, Langsa City, the obstacles when filling out the recitation, and the implications for their social and religious activities in Langsa City. The number of taklim assemblies recorded in the list of recapitulation of the Office of Islamic Shari'a and Dayah Education in Langsa City is 195 taklim assemblies. Officially, these two taklim assemblies have not been included in the list compiled by the Office of the Office of Islamic Shari' a and Dayah Education in Langsa City. However, the recitation activities of the two taklim councils are quite unique. In addition, the congregation is dominated by socialite mothers with a variety of religious materials and full social activities in a week. After carrying out the process of gathering information through in-depth interviews with Ustadz at the Amanah and Hidayatullah Taklim Council and through observation of assistance and participants, this study found that the andragogy approach process in these two taklim assemblies was very special, namely using a dialogical approach, psychological, and religious as contained in the concepts and principles of the andragogy approach. So that the implication in social and religious activities is that the socialites of Langsa City are able to provide positive benefits for people's lives.
\end{abstract}

Keywords: Approach; Andragogy; Socialite.

Abstrak: Artikel ini membahas tentang proses pendekatan andragogi yang dilakukan para Ustadz pemateri saat mengisi pengajian Ibu-ibu sosialita yang aktif di Majelis Taklim Amanah dan Majelis Taklim Hidayatullah Kota Langsa, kendala saat mengisi pengajian, dan implikasinya dalam aktivitas sosial dan keagamaan mereka di Kota Langsa. Jumlah majelis taklim yang tercatat dalam daftar rekapitulasi Dinas Syariat Islam dan Pendidikan Dayah Kota Langsa sebanyak 195 majelis taklim. Secara resmi, dua majelis taklim ini memang belum tercantum dalam daftar yang dihimpun oleh Kantor Dinas Syariat Islam dan Pendidikan Dayah Kota Langsa. Namun, kegiatan pengajian dua majelis taklim tersebut terbilang sangat unik. Selain jama'ahnya didominasi oleh Ibu-ibu sosialita dengan aneka ragan materi keagamaan serta kegiatan sosial penuh dalam sepekan. Setelah melakukan proses penghimpunan informasi melalui wawancara mendalam (in-defth interview) dengan para Ustadz di Majelis Taklim Amanah dan Hidayatullah dan melalui observasi asistensi serta partisipan, penelitian ini menemukan bahwa proses pendekatan andragogi dalam dua majelis taklim ini sangat istimewa, yaitu menggunakan pendekatan dialogis, psikologis, dan agamis sebagaimana yang terdapat dalam konsep dan prinsip-prinsip pendekatan andragogi. Sehingga implikasinya dalam aktivitas sosial dan keagamaan Ibu-ibu sosialita Kota Langsa mampu memberikan manfaat positif bagi kehidupan masyarakat.

Kata Kunci: Andragogi; Pendekatan; Sosialita.

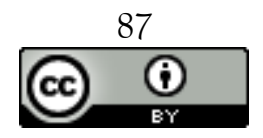

This work is licensed under a Creative Commons Attribution 4.0 International License 


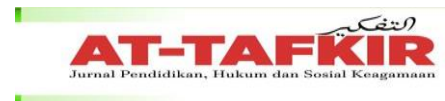

\section{VOLUME 14 NOMOR I TAHUN 2021 \\ P-ISSN : 1979-9357 \\ E-ISSN : 2620-5858}

\section{PENDAHULUAN}

Pendidikan tidak terbatas pada jalur formal yang diperoleh melalui lembaga pendidikan seperti sekolah, jalur informal yang ditempuh lewat pendidikan kelurga, maupun jalur nonformal dari masyarakat. Hal ini berujuan untuk meningkatan kualitas diri. Hal tersebut karena sejatinya pendidikan merupakan suatu proses yang kompleks di mana semua komponen merupakan satu kesatuan yang kehadirannya dapat saling melengkapi dan menyempurnakan (Ideharnida \& dkk, 2018). Kebutuhan terhadap pendidikan tidak terbatas pada kalangan tertentu, namun dibutuhkan oleh semua kalangan. Bahkan dalam Islam, pendidikan sejatinya dilakukan sejak buaian hingga ke liang lahat. Maka salah satu aspek yang harus ditunaikan adalah pemenuhan hak akal melalui pemberian nutrisi berupa ilmu pengetahuan.

Konsep pendidikan seumur hidup (life long education) telah berkembang secara pesat di tengah-tengah kehidupan masyarakat. Pendidikan orang dewasa dilakukan untuk memenuhi kebutuhan belajar sepanjang hayat selama masyarakat itu ada. Masyarakat memperoleh pengetahuan, keterampilan, dan pemahaman lainnya tidak hanya cukup dengan formal saja, tetapi masyarakat juga perlu memperoleh pendidikan lain sebagai complementary, baik melalui pendidikan informal maupun nonformal (Kamil, 2009). Tujuannya untuk membantu masyarakat menghadapi sesuatu persoalan hidup mereka secara objektif, memperlengkapi keterampilan memecahkan masalah, membantu masyarakat dalam mengubah kondisi sosial mereka, dan membantu masyarakat memperoleh pengetahuan atau keterampilan yang diperlukan guna melengkapi kebutuhan hidup mereka. Hal ini didasari oleh pendapat bahwa di tengah pesatnya perkembangan ilmu pengetahuan dan teknologi, orang dewasa merasakan kekurangan akan keterampilan yang selama ini dimiliki dan sekaligus memerlukan keterampilanketerampilan baru yang relevan (Jeosoef, 2008).

Untuk menyahuti kebutuhan tersebut, dibentuklah lembaga kursus atau sejenis pelatihan di masyarakat yang memiliki program melatih orang dewasa untuk menguasai keterampilan pada jenis pekerjaan tertentu maupun untuk jenis pekerjaan dalam lingkup yang sangat luas. Selain lembaga kursus dan pelatihan, aktivitas belajar orang dewasa di masyarakat juga berkembang dalam wujud majelis taklim. Dalam praktiknya, majelis taklim merupakan tempat pengajaran atau pendidikan agama Islam yang paling fleksibel dan tidak terikat waktu serta tempat. Majelis taklim bersifat terbuka terhadap segala usia, lapisan atau strata sosial dan jenis kelamin. Fleksibelitas majelis taklim inilah yang menjadi kekuatan sehingga mampu bertahan dan merupakan lembaga pendidikan Islam yang paling dekat dengan umat (masyarakat). Dengan demikian, majelis taklim menjadi lembaga pendidikan alternatif bagi Jemaah (para orang tua khususnya) yang tidak memiliki cukup tenaga, waktu, dan kesempatan menimba ilmu keagamaan di jalur pendidikan formal.

Majelis taklim berperan dalam mewujudkan pembelajaran seumur hidup (life long education). Urgensitas majelis taklim inilah menjadi salah satu solusi bagi masyarakat

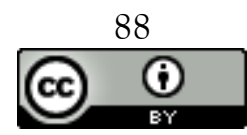

This work is licensed under a Creative Commons Attribution 4.0 International License 


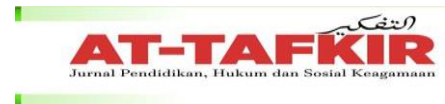

\section{VOLUME 14 NOMOR I TAHUN 2021 \\ P-ISSN : 1979-9357 \\ E-ISSN : 2620-5858}

untuk menambah dan melengkapi pengetahuan yang kurang dan belum sempat mereka peroleh di lembaga pendidikan formal (Helmawati, 2013).

Berdasarkan sumber data dari Kantor Dinas Syariat Islam dan Pendidikan Dayah Kota Langsa, terdapat 195 majelis taklim dan dzikir yang tercatat dan tersebar di 5 Kecamatan: Kecamatan Langsa Kota, Kecamatan Langsa Baro, Kecamatan Langsa Barat, Kecamatan Langsa Lama, dan Kecamatan Langsa Timur. Selain 195 majelis taklim yang tercatat di Kantor Dinas Syariat Islam, sebetulnya masih banyak yang belum tercatat, namun Badan Kemakmuran Masjid (BKM), mushalla, dan majelis taklim lainnya belum memberikan laporan (Dayah, 2020). Artikel ini akan menjelaskan proses pendekatan andragogi dalam pengajian ibu-ibu sosialita yang ada pada Majelis Taklim Amanah dan Majelis Taklim Hidayatullah, masalah dan kendala yang terjadi, serta implikasinya dalam aktivitas sosial dan keagamaan mereka di Kota Langsa.

\section{METODE PENELITIAN}

Pendekatan yang digunakan dalam penelitian ini adalah format kualitatif. Subyek penelitian adalah majelis taklim yang diikuti oleh mayoritas sosialita kota Langsa, yakni majelis taklim Amanah dan Hidayatullah yang belum terdaftar secara resmi pada Dinas Syariat Islam dan Pendidikan Dayah Kota Langsa. Alat pengumpul data adalah berupa observasi dan wawancara. Data yang diperoleh kemudian dianalisis melalui tahapan pengumpulan data, reduksi data, display data, dan verifikasi (Moleong, 2017).

\section{HASIL DAN PEMBAHASAN \\ Definisi Andragogi}

Andragogi berasal dari bahasa Yunani yang terdiri dari dua kata yaitu andr yang artinya orang dewasa dan agogos yang artinya memimpin dan membimbing. Maka andragogi adalah seni dan ilmu membantu orang dewasa belajar (Knowles M. S., 1980). Andragogi secara etimologi adalah sebagai teori pembelajaran sangat penting untuk diketahui dan dipahami, sebab paradigma tentang pembelajaran yang didasarkan pada rumusan pendidikan sebagai suatu proses transmisi budaya, yang melahirkan pedagogi yaitu ilmu seni mengajar anak-anak. Orang dewasa yang dimaksud secara fisik (biologis) adalah cukup berumur (Arif, 1994).

Knowles menyatakan bahwa andragogi adalah the art and science of helping adult learn, yaitu seni dan ilmu yang berkaitan dengan cara-cara membantu orang dewasa belajar. Hal itu berbeda dengan pedagogi, yaitu sebagai the art and science of teaching children atau seni dan ilmu yang berkaitan dengan cara mengajar anak. Pendekatan andragogi mempunyai beberapa asumsi dasar, di antaranya yang cukup dikenal ada empat hal, yaitu (l) selfdirectedness atau kemampuan mengarahkan diri, (2) pengalaman pembelajar atau mahasiswa, (3) kesiapan belajar berdasarkan kebutuhan, dan (4) orientasi bahwa belajar itu adalah kehidupan (Knowles M. S., 1995). Dari definisi di atas dapat dipahami, bahwa andragogi merupakan bagian dari ilmu pendidikan yang secara khusus diperuntukkan bagi orang-orang dewasa.

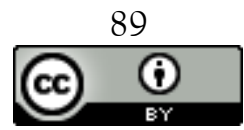

This work is licensed under a Creative Commons Attribution 4.0 International License 


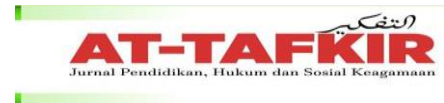

VOLUME 14 NOMOR I TAHUN 2021

P-ISSN : 1979-9357

E-ISSN : 2620-5858

\section{Varian Makna Sosialita}

Menurut Nadia Mulya, kata sosialita mulai digunakan sejak tahun 1928. Mereka juga menyatakan bahwa, orang-orang yang termasuk dalam kategori ini adalah orang yang superkaya yang kebanyakan keturunan bangsawan, aktif dikegiatan sosial dan kerap mengadakan pesta atau diundang dalam event bergengsi dan fashionable (Roesma \& Mulya, 2013). Hal ini diperkuat oleh Inti Soebagio menyatakan bahwa kata socialite yang berarti sosialita diambil dari kata "social" dan "elite". Social berarti sosial dan elite berarti elit atau kelas atas (Roesma \& Mulya, 2013).

Mirah mengartikan sosialita juga merupakan sebutan yang diberikan kepada perempuan yang bisa digolongkan sebagai kelompok perempuan yang sudah memiliki kemampuan dan kemauan serta fasilitas, kesempatan, dan sarana yang cukup bagi. Sedangkan Veruschka mengatakan bahwa jika di Indonesia ada anggapan bahwa apabila seseorang mampu untuk membeli tas Hermès, sepatu Louboutin dan Charlotte Olympia, atau sering mendapat undangan dan muncul di event gaya hidup, maka orang tersebut sudah bisa dianggap menjadi bagian dari sosialita. Karenanya tidak mengherankan jika akhirnya dunia sosialita dan selebriti, bagi sebagian besar wanita daya pikatnya sungguh luar biasa (Roesma \& Mulya, 2013).

Sementara itu menurut Boedi Basuki, sosialita memang sudah jelas artinya dan istilah tersebut memang bergengsi akan tetapi pada kenyataannya the real social darlings itu justru tidak mau untuk menunjukan eksistensi mereka dan bahkan tidak mau diasosiasikan dengan gelar sosialita karena gengsinya yang sudah menurun. Boedi mengamati, media yang mengangkat profil dan acara para sosialita semakin banyak dan tak terbatas pada media cetak, melainkan melebar ke televisi. Gempuran media yang mengekspos kehidupan mewah kaum sosialita ini juga membuat semakin banyak orang, terutama wanita, mendambakan reputasi sosialita dan diekspos ke publik." (Roesma \& Mulya, 2013).

Berdasarkan penjelasan di atas, dapat dipahami bahwa sosialita merupakan sebuah istilah dan sebutan yang diberikan kepada kaum wanita yang dapat digolongkan sebagai kelompok atau komunitas wanita yang memiliki kemampuan dan kemauan serta fasilitas, kesempatan, dan sarana yang serba tersedia bagi perannya. Namun, seiring perjalanan waktu dan perputaran zaman, makna sosialita mengalami pergeseran makna. Hal itu terjadi tidak terlepas dari bagaimana proses komunikasi itu terjadi. Adapun sosialita yang penulis maksud dalam artikel ini adalah Ibu-ibu jama'ah pengajian yang tergabung dalam Majelis Taklim Amanah dan Majelis Taklim Hidayatullah yang mayoritas terdiri dari kalangan menengah ke atas dan aktif mengikuti jadwal kegiatan pengajian serta memiliki jiwa kepedulian sosial.

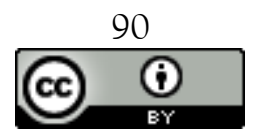

This work is licensed under a Creative Commons Attribution 4.0 International License 


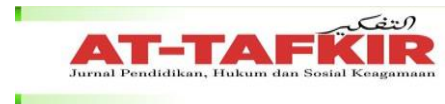

\section{VOLUME 14 NOMOR I TAHUN 2021 \\ P-ISSN : 1979-9357 \\ E-ISSN : 2620-5858}

\section{Tujuan Pendidikan Terhadap Orang Dewasa (Andragogi)}

Secara umum, pendidikan orang dewasa bertujuan untuk membantu pembelajar dewasa memiliki pengetahuan, pengalaman dan keterampilan guna meningkatkan kesejahteraan dalam kehidupannya. Karena itulah kegiatan inti dalam pembelajaran orang dewasa lebih disesuaikan dengan kebutuhan dan target yang ingin dicapai oleh para pembelajar dewasa untuk keperluan dalam waktu dekat. Selain itu, pembelajaran orang dewasa juga bertujuan untuk membantu pembelajar dewasa memahami dirinya sendiri, bakatnya, keterbatasannya, dan hubungan interpersonalnya. Di samping itu, pendidikan orang dewasa juga bertujuan membantu pembelajar dewasa mencapai kemajuan proses pematangan secara intelektual, emosional, dan spiritual. Dalam mengikuti proses pendidikan, orang dewasa dilatih dan dibiasakan mengembangkan paradigm berpikir, kesadaran, inisiatif, dan tanggung jawab, kepedulian sosial, dan memiliki karakter terpuji sebagai makhluk yang memiliki keyakinan kepada Tuhan. Melalui pengetahuan, pengalaman, dan keterampilan yang diperoleh lewat pendidikan, dapat membantu orang dewasa untuk melakukan perubahan sosial dalam lingkungan masyarakatnya (Al-Farabi, 2018).

\section{Karakteristik Pendidik Orang Dewasa}

Bagi para pendidik dan pengajar usia dewasa penting memiliki kecakapan, pemahaman untuk terwujudnya proses dan tujuan pembelajaran sebagaimana yang diharapkan. Untuk itu, karakteristik pendidik orang dewasa itu antara lain harus memiliki beberapa kemampuan sebagai berikut:

a. Memiliki Keahlian dalam Mengelola Pembelajaran

Fungsi utama dari seorang tutor (fasilitator) dalam kegiatan yang bersifat andragogi adalah mengatur dan membimbing proses andragogi itu sendiri, ketimbang mengatur isi pelajaran sebagaimana halnya dalam pedagogi. Isi kegiatan belajar secara andragogi sangat beraneka ragam tergantung pada sumber-sumber belajar sertaa minat atau kebutuhan peserta didik. Adapun fasilitator tidak diperlukan sebagai ahli dalam ini pelajaran, tetapi diperlukan sebagai proses andragogi itu berjalan secara efektif. Karena itu diharapkan agar fasilitator dapat mengetahui sedikit banyak mengenai isi pengetahuan.

Oleh sebab itu, andragogi sebagai kegiatan pendidikan yang berkelanjutan bagi orang dewasa merupakan: (1) Cara untuk belajar secara langsung dari pengalaman; (2) Suatu proses pendidikan kembali yang dapat mengurangi konflikkonflik social melalui kegiatan-kegiatan antara pribadi dalam kelompok belajar; (3) Suatu proses diarahkan sendiri, di mana pendidik secara terus-menerus dapat menilai kembali kebutuhan belajar yang timbul dari situasi yang selalu berubah; (4) Dengan demikian, kalau ditarik pengertiannya sejalan dengan pedagogi, maka andragogi secara harfiah dapat diartikan sebagai ilmu dan seni membantu atau membimbing orang dewasa belajar. Namun karena orang dewasa sebagai individu yang sudah mandiri dan mampu mengarahkan dirinya sendiri, maka dalam

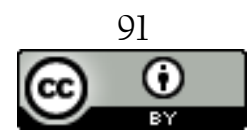

This work is licensed under a Creative Commons Attribution 4.0 International License 


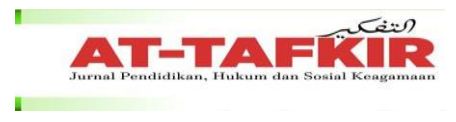

\section{VOLUME 14 NOMOR I TAHUN 2021 \\ P-ISSN : 1979-9357 \\ E-ISSN : 2620-5858}

andragogi yang terpenting dalam proses interaksi belajar adalah kegiatan belajar mandiri yang bertumpu kepada peserta didik itu sendiri dan bukan seperti seorang guru mengajarkan sesuatu kepada murid-muridnya.

b. Memiliki Banyak Pengalaman Hidup dan Mampu Membaca Situasi

Seorang pelatih harus mampu membaca situasi perilaku dari peserta pelatihan untuk mengarahkan pada tujuan tersebut. Hal ini didasarkan prinsip-prinsip teori perilaku, bahwa prinsip yang paling penting dari teori belajar perilaku yakni perilaku berubah menurut konsekuensi-konsekuensi yang menyenangkan akan memperkuat perilaku, sedangkan konsekuensi-konsekuensi yang tidak menyenangkan akan melemahkan perilaku.

Asumsi-asumsi pokok menggunakan pendekatan andragogi berdasar pada empat asumsi: (1) Bahwa orang dewasa mengarahkan tujuan belajarnya sendiri; (2) Bahwa pengetahuan yang telah dimiliknya merupakan sumber belajar untuk pembelajaran selanjutnya; (3) Bahwa orang dewasa belajar setelah ia sendiri merasa ingin belajar, kegiatan belajar adalah untuk memenuhi kebutuhan hidup (rumah, pekerjaan, dan sebagainya); (4) Orang dewasa belajar karena mencari kompetensi untuk memenuhi kebutuhannya yang lebih tinggi, seperti kebutuhan untuk pengembangan potensi diri, mereka ingin merasakan hasil dari belajarnya, apa yang dipelajari harus dapat dirasakan (Al-Farabi, 2018).

\section{Karakteristik Pembelajar Dewasa}

Dalam aplikasinya, pendidik atau fasilitator bagi pembelajar dewasa sangat berbeda dengan pembelajar anak-anak. Sebab pembelajar dewasa memiliki karakteristik yang tidak dimiliki pembelajar usia anak-anak. Sudarwan Danim mencoba merincikan beberapa karakteristik pembelajar dewasa, sebagai berikut: (1) Pembelajar dewasa biasanya memiliki maksud yang teridentifikasi; (2) Pembelajar dewasa biasanya memiliki pengalaman sebelumnya, baik positif maupun negatif, dengan pendidikan diselenggarakan; (3) Pembelajar dewasa ingin segera mengambil manfaat dari hasil belajarnya; (4) Pembelajar dewasa memiliki konsep diri secara satu arah; (5) Pembelajar dewasa membawa dirinya dengan reservoir pengalaman; (6) Pembelajar dewasa membawa keraguan dan ketakutan yang luas bagi proses pendidikan; (7) Pembelajar dewasa biasanya sangat kuat pada ketahanan perubahan; (8) Gaya pembelajar dewasa biasanya diatur; (9) Pembelajar dewasa memiliki tujuan yang dewasa; (10) Masalah pembelajar dewasa yang berbeda dari masalah anak-anak; (11) Pembelajar dewasa biasanya memiliki sebuah keluarga mapan; (12) Waktu reaksi pembelajar orang dewasa sering lambat; (13) Minat pendidikan pembelajar dewasa biasanya mencerminkan dimensi kejujuran; (14) Nilai-nilai diri pembelajar dewasa sebagai orang dewasa lebih banyak daripada nilai-nilai program (Danim, 2015).

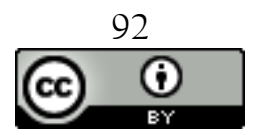

This work is licensed under a Creative Commons Attribution 4.0 International License 
VOLUME 14 NOMOR I TAHUN 2021

P-ISSN : 1979-9357

E-ISSN : 2620-5858

\section{Faktor-faktor yang Mempengaruhi Pendidikan Orang Dewasa}

Belajar sebagai proses atau aktivitas disyaratkan oleh banyak sekali hal-hal atau faktor-faktor. Faktor-faktor yang mempengaruhi belajar itu banyak sekali macamnya, terlalu banyak untuk disebutkan satu per satu. Secara umum, Sumadi Suryabrata menyatakan, bahwa faktor-faktor tersebut dapat diklasifikasikan menjadi dua golongan (Suryabrata, 2008):

1. Faktor-faktor yang berasal dari luar diri, dan ini masih lagi dapat digolongkan menjadi dua golongan, yaitu: (a) Faktor-faktor nonsosial; dan (b) Faktor-faktor sosial.

2. Faktor-faktor yang berasal dari dalam diri, dan ini pun dapat lagi digolongkan menjadi dua golongan, yaitu: (a) Faktor-faktor fisiologis; dan (b) Faktor-faktor psikologis.

Faktor-faktor nonsosial dalam belajar boleh dikatakan tak terbilang jumlahnya, seperti: keadaan udara, suhu udara, cuaca, waktu (pagi, atau siang, ataupun malam), tempat, alat-alat yang dipakai untuk belajar. Sedangkan faktor-faktor sosial di sini maksudnya adalah faktor manusia, baik manusia itu hadir ataupun tidak. Kehadiran orang lain pada waktu seseorang sedang belajar banyak sekali mengganggu belajar.

Adapun secara garis besar, ada dua faktor yang dapat mempengaruhi pendidikan orang dewasa, yaitu faktor internal dan eksternal. Faktor internal adalah segala faktor yang bersumber dari dalam diri peserta didik yang belajar, seperti faktor fisik dan faktor psikis. faktor fisik mencakup pendengaran, penglihatan, dan kondisi fisiologis lainnya, sedangkan faktor psikis mencakup kebutuhan, kecerdasan, motivasi, perhatian, berpikir, ingatan, dan lupa. Adapun faktor eksternal adalah segala faktor yang bersumber dari luar diri peserta didik, seperti faktor lingkungan belajar dan faktor sistem penyajian. Dalam hal ini, faktor lingkungan belajar mencakup lingkungan alam, fisik, dan sosial, sedangkan faktor sistem penyajian mencakup kurikulum, bahan ajar, dan metode pembelajaran.

Secara terperinci, faktor-faktor yang mempengaruhi pendidikan atau proses belajarnya orang dewasa tersebut dapat diuraikan pada pembahasan berikut ini:

1. Faktor Fisik

Faktor sangat menentukan kesuksesan atau kegagalan orang dewasa dalam belajar. Ada korelasi negatif antara pertambahan usia dengan kemampuan belajar orang dewasa. Maksudnya, makin bertambah usia individu dewasa, maka akan semakin sukar baginya belajar (karena semua aspek kemampuan fisiknya semakin menurun). Misalnya pendengaran, penglihatan, kekuatan tubuh, kemampuan menalar, dan kemampuan berkonsentrasi semuanya memperlihatkan penurunannya sesuai pertambahan usianya pula.

2. Faktor Psikis

Selain faktor fisik, faktor psikis berpengaruh besar dalam menentukan kesuksesan atau kegagalan orang dewasa dalam belajar. Faktor psikis yang mempengaruhi proses interaksi belajar orang dewasa pada garis besarnya dapat dikeompokkan atas aspek kecerdasan/bakat, motivasi, perhatian, perpikir, dan ingatan/lupa.

a. Kecerdasan/Bakat

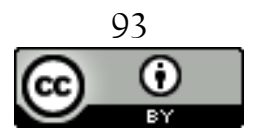

This work is licensed under a Creative Commons Attribution 4.0 International License 


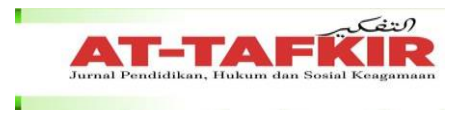

\section{VOLUME 14 NOMOR I TAHUN 2021 \\ P-ISSN : 1979-9357 \\ E-ISSN : 2620-5858}

Kecerdasan/bakat merupakan salah satu faktor penting yang menentukan berhasil atau tidaknya seseorang dalam mengikuti suatu kegiatan belajar tertentu. Tugas pendidik yakni mengembangkan seoptimal mungkin potensi kecerdasan/bakat warga belajar dalam mempelajari suatu bahan ajar.Tentang terbentuknya potensi kecerdasan ini, teori periode kritis yang dikembangkan oleh Bloom mengemukakan, bahwa \pm 50 persen kecerdasan yang dimiliki orang dewasa diperoleh pada usia +4 tahun dan +80 persen didapat pada usia \pm 8 tahun. Hal itu berarti, bahwa masa pendidikan di TK dan di SD merupakan pengalaman belajar yang paling penting dalam kehidupan seseorang. Ahli lain mengemukakan, bahwa lingkungan yang melarat pada usia kanak-kanak dapat menyebabkan seseorang mengalami kehilangan atau lambat kecerdasan kira-kira 2,5 IQ per tahun (Basleman \& Mappa, 2011).

\section{Metode dan Teknik Pembelajaran Orang Dewasa}

Karakteristik metode pembelajaran untuk orang dewasa adalah luwes, terbuka, dan partisipatif. Luwes adalah dapat dimodifikasi dalam penggunaannya. Terbuka maksudnya dalam menerima masukan untuk perubahan dan pengembangan metode. Partisipatif berarti, bahwa peserta didik diikutsertakan dalam perencanaan, pelaksanaan, dan evaluasi pembelajaran. Model pembelajaran yang dipandang cocok dengan karakteristik metode pembelajaran adalah model pembelajaran partisipatif. Dalam andragogi, pembelajaran partisipatif adalah upaya pendidik melibatkan peserta pelatihan dalam perencanaan, pelaksanaan, dan penilaian. Pembelajaran partisipatif didasarkan oleh prinsip-prinsip: (1) Berdasarkan kebutuhan belajar (learning-needs based); (2) Berorientasi pada pencapaian tujuan (goals and objectives oriented); (3) Berpusat pada peserta pelatihan (participants centered); dan (4) Belajar berdasarkan pengalaman atau mengalami (experiential learning) (Sudjana, 1991).

Pembelajaran teori untuk orang dewasa hendaknya berpusat pada masalah belajar, memotivasi mereka untuk aktif dalam latihan, mengemukakan pengalamannya, membangun kerja sama antara instruktur dengan peserta latihan dan antara sesama peserta latihan, memberikan pengalaman belajar dan bukan pemindahan atau penyerapan materi. Selanjutnya, pada pembelajaran praktik, orang dewasa diarahkan dapat meningkatkan produktivitas, memperbaiki kualitas kerja, mengembangkan keterampilan baru, membantu menggunakan alat-alat dengan cara yang tepat, dan meningkatkan keterampilan (Sudjana, 1991).

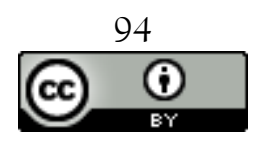

This work is licensed under a Creative Commons Attribution 4.0 International License 


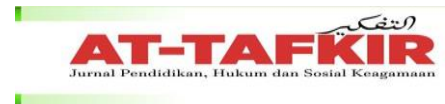

\section{VOLUME 14 NOMOR I TAHUN 2021 \\ P-ISSN : 1979-9357 \\ E-ISSN : 2620-5858}

\section{Pendekatan Andragogi dalam Pengajian Ibu-ibu Sosialita di Kota Langsa}

Jama'ah pengajian Ibu-ibu sosialita yang tergabung di dalam Majelis Taklim Amanah dan Majelis Taklim Hidayatullah memiliki kesamaan pendekatan yang dilakukan oleh ustadz-ustadz pengajar dua majelis taklim tersebut. Sebagaimana teori dan konsep yang terdapat dalam pendekatan andragogi, bahwa ada beberapa hal masalah pokok dalam pembelajaran orang dewasa di antaranya, yaitu: (1) Lemahnya motivasi. Banyak orang dewasa merasa bahwa mereka sukar dilatih. Mereka kurang bisa menyesuaikan diri dengan perubahan, dan terlalu tua untuk belajar, sehingga motivasi mereka rendah dalam mengikuti pembelajaran; (2) Sulit melupakan kebiasaan. Orang dewasa sering mempunyai kesulitan untuk memperbaiki kesalahan yang telah menjadi kebiasaan. Mereka cenderung mengulangi terus menerus walaupun tahu bahwa mereka berbuat salah (Daryanto \& Tarno, 2017).

Berdasarkan hasil wawancara mendalam dengan Ustadz-ustadz yang mengisi pengajian di Majelis Taklim Amanah dan Majelis Taklim Hidayatullah, bahwa ada kesamaan pendekatan yang mereka lakukan sebelum memulai pengajian. Seperti pendekatan yang dilakukan oleh Ustadz $\mathrm{AH}$, bahwa pembelajaran yang beliau lakukan biasanya diawali dengan pemberian motivasi dan menjelaskan keutamaan orang-orang yang hadir dan rutin mengikuti kajian.

Jadi dapat dikatakan bahwa, pendekatan yang telah diaplikasikan para Ustadz AH dalam mengajar jama'ah Ibu-ibu di Majelis Taklim Amanah dan Hidayatullah sesuai dengan yang dinyatakan Mohammad Al-Farabi, bahwa seorang guru atau pelatih harus mampu membaca situasi perilaku dari peserta pelatihan untuk mengarahkan pada tujuan tersebut. Hal ini didasarkan prinsip-prinsip teori perilaku, bahwa prinsip yang paling penting dari teori belajar perilaku yakni perilaku berubah menurut konsekuensikonsekuensi yang menyenangkan akan memperkuat perilaku, sedangkan konsekuensikonsekuensi yang tidak menyenangkan akan melemahkan perilaku. Ustadz-ustadz yang lainnya, Ustadz DW, Ustadz ZZ, Ustadz AA juga melakukan hal yang serupa. Meskipun belum pernah berkoordinasi dan berkomunikasi mengenai teknik pendekatan dengan Ibu-ibu dalam pengajian, para Ustadz-ustadz tersebut sangat memahami secara psikologis bagaimana seharusnya mereka menghadapi dan memperlakukan para jama'ah Ibu-ibu yang memiliki latar belakang sosial mayoritas kelas menengah ke atas yang sudah rela hadir di majelis taklim.

Sementara itu, dalam hal kendala teknis yang dihadapi para Ustadz-ustadz saat mengisi pengajian, mereka mengungkapkan bahwa tidak ada kendala dan masalah yang sangat serius. Kalaupun ada, masalah dan kendala yang terjadi selalu dapat dimaklumi mengingat latar belakang masing-masing yang berbeda-beda. Seperti, keterlambatan dalam kehadiran dan izin pulang lebih dulu karena ada urusan keluarga dan urusan lainnya.

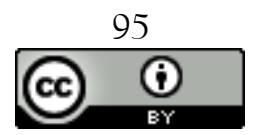

This work is licensed under a Creative Commons Attribution 4.0 International License 


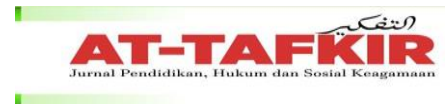

\section{VOLUME 14 NOMOR I TAHUN 2021 \\ P-ISSN : 1979-9357 \\ E-ISSN : 2620-5858}

\section{Implikasi Pendekatan Andragogi dalam Pengajian Ibu-ibu Sosialita di Kota Langsa}

Pendekatan andragogi yang diterapkan Ustadz-ustadz bukan hanya pada saat pengajian sedang berlangsung di lokasi Majelis Taklim Amanah dan Majelis Taklim Hidayatullah saja, namun pendekatan juga terjadi di luar pengajian. Seperti yang dialami oleh Ustadz DW mengungkapkan pentingnya komunikasi berkelanjutan di luar pengajian, misalnya melayani pertanyaan yang belum sempat ditanyakan pada kajian ataupun hal-hal lain di luar kajian, bahkan sampai pemberian nasehat serta solusi. Begitu juga yang dialami oleh Ustadz AH yang memberi kesempatan untuk konsultasi seputar masalah agama di luar kajian bahkan diperbolehkan datang ke rumah.

Tidak berbeda dengan Ustadz lainnya, tidak jauh berbeda. Ini menunjukkan, bahwa pendekatan andragogi bukan hanya ada dalam suasana pengajian, tapi juga di luar pengajian. Sehingga implikasi dari pendekatan yang ada memberikan dampak positif bagi keinginan dan motivasi jama'ah Ibu-ibu untuk bisa hadir serta mengikuti pengajian. Dan implikasi yang dirasakan oleh para jama'ah Ibu-ibu secara individu seperti, semakin bertambahnya semangat mengikuti setiap kajian-kajian yang digelar oleh Majelis Taklim Amanah dan Majelis Taklim Hidayatullah.

Sedangkan implikasi secara sosial keagamaan, jama'ah Ibu-ibu sosialita ini memiliki semangat kepedulian sosial, seperti: adanya rasa hormat pada Ustadz dan guru yang mengajar, hal ini dibuktikan dengan setiap tiba hari raya Idul Fitri dan Idul Adha selalu mengadakan kunjungan silaturrahmi ke rumah para guru mereka, menjenguk guru dan jama'ah yang ditimpa musibah, munculnya rasa kepedulian sosial untuk berbagi AlQur'an dan peralatan shalat (mukena) bagi kaum fakir miskin, kaum dhuafa, santri dan santriwati di beberapa dayah dan pesantren di Kota Langsa, dan berbagi bahan makanan pokok bagi kaum fakir miskin di daerah Pusong.

\section{Kesimpulan}

Berdasarkan hasil yang telah didapatkan dan dipaparkan di atas, kesimpulan penelitian ini menemukan sebagai berikut: Pertama, proses pendekatan andragogi dalam dua majelis taklim ini sangat unik dan istimewa, yaitu menggunakan pendekatan secara dialogis, psikologis, dan agamis sebagaimana yang terdapat dalam prinsip-prinsip pendekatan andragogi. Kedua, kendala yang dihadapi para Ustadz-ustadz pada saat mengajar selalu dapat dimaklumi, mengingat latar belakang Ibu-ibu sosialita tersebut berbeda-beda. Ketiga, implikasi dari pendekatan andraogi baik di dalam pengajian maupun di luar pengajian terhadap aktivitas Ibu-ibu sosialita Kota Langsa adalah mereka dapat memberikan manfaat yang sangat baik dan luar biasa bagi kehidupan masyarakat. Terutama dalam hal melestarikan budaya mempelajari dan meningkatkan bacaan AlQur'an serta terus mempelajari ilmu-ilmu agama hingga akhir hayat (life long education) serta berbagi kebutuhan pokok makanan dan sarana beribadah.

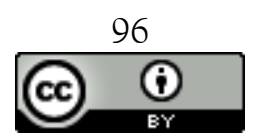

This work is licensed under a Creative Commons Attribution 4.0 International License 


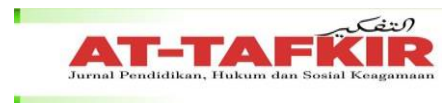

\section{VOLUME 14 NOMOR I TAHUN 2021 \\ P-ISSN : 1979-9357 \\ E-ISSN : 2620-5858}

\section{DAFTAR PUSTAKA}

Al-Farabi, M. (2018). Pendidikan Orang Dewasa dalam Al-Qur'an (1 ed.). Jakarta: Kencana. Arif, Z. (1994). Andragogi (Dua ed.). Bandung: Angkasa.

Basleman, A., \& Mappa, S. (2011). Teori Belajar Orang Dewasa. Bandung: Remaja Rosdakarya.

Danim, S. (2015). Pedagogi, Andragogi, dan Heutagogi (3 ed.). Bandung: Alfabeta.

Daryanto, \& Tarno, H. (2017). Pendidikan Orang Dewasa (POD) (1 ed.). Yogyakarta: Gaya Media.

Dayah, D. S. (2020). Daftar Rekapitulasi Gampong yang telah melaksanakan pengajian rutin di Masjid dan Majelis-majelis Taklim lainnya di wilayah Kota Langsa Tahun 2020. Langsa.

Helmawati. (2013). Pendidikan Nasional dan Optimalisasi Majelis Taklim: Peran Aktif Majelis Taklim Meningkatkan Mutu Pendidikan. Bandung: Rineka Cipta.

Ideharnida, D., \& dkk. (2018, Maret). Pembelajaran Membaca Al-Qur'an Bagi Orang Dewasa (Studi Kasus Pada Kelas Talaqqi Dasar dan Talaqqi Plus di Lembaga Pendidikan Al-Qur'an Ash Habul Qur'an Kota Payakumbuh). Spektrum:Jurnal Pendidikan Luar Sekolah (PLS), l(1).

Jeosoef, S. (2008). Konsep Dasar Pendidikan Luas Sekolah. Jakarta: Bumi Aksara.

Kamil, M. (2009). Pendidikan Nonformal: Pengembangan Melalui Pusat Kegiatan Belajar Mengajar (PKBM) di Indonesia. Bandung: Alfabeta.

Knowles, M. S. (1980). The Modern Practice of Adult Education, Andragogy Versus Pedagogi. New York: Assosiation Press.

Knowles, M. S. (1995). The Modern Practice of Adult Education: From Pedagogy to Andragogy dan Torsten Husen T. Nevile Postlethwait The International Encyclopedia of Education (Second Edition ed., Vol. II). Oxford: Pergamon.

Moleong, L. J. (2017). Metodologi Penelitian Kualitatif. Jakarta: Remaja Rosda Karya.

Roesma, J., \& Mulya, N. (2013). The Untold Stories of Arisan Ladies and Socialite. Jakarta: PT. Gramedia.

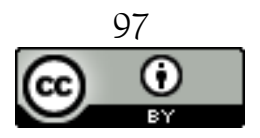

This work is licensed under a Creative Commons Attribution 4.0 International License 


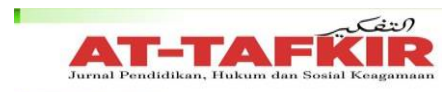

【

VOLUME 14 NOMOR I TAHUN 2021

P-ISSN : 1979-9357

E-ISSN : 2620-5858

Sudjana, D. (1991). Pendidikan Luar Sekolah: Wawasan Sejarah Perkembangan Falsafah $\sim$ Teori Pendukung Asas. Bandung: Nusantara Press.

Suryabrata, S. (2008). Psikologi Pendidikan. Jakarta: PT. Raja Grafindo Persada. 